\title{
Evaluation of the Relationship between Silent Cerebral Lesions and Triglyceride/HDL-Cholesterol in Patients with First Stroke Attack
}

\author{
İlk İnme Atağı Olan Olgularda Sessiz Serebral Lezyonların Trigliserid/HDL-Kolesterol Oranı ile \\ İlişkisinin Değerlendirilmesi
}

\author{
ESRa ACIMAN DEMIREL \\ (1) 0000-0002-1444-5022 \\ Gülcan KALAYCI \\ (D) 0000-0003-2046-6759 \\ Mustafa AÇIKGÖZ \\ (D) 0000-0002-0645-5765 \\ Ulufer ÇELEBİ \\ (D) 0000-0001-5785-3379 \\ Bilge PÍRİ ÇINAR \\ (D) 0000-0002-4884-0717 \\ Hüseyin Tuğrul ATASOY \\ (10) 0000-0003-1631-7400
}

Bulent Ecevit University Faculty of Medicine Department of Neurology, Zonguldak, Turkey

\section{Corresponding Author Sorumlu Yazar \\ Esra ACIMAN DEMIREL \\ esraaciman@yahoo.com}

Received / Geliş Tarihi : 15.05.2020 Accepted / Kabul Tarihi : 18.11.2020 Available Online /

Çevrimiçi Yayın Tarihi : 25.12.2020

\begin{abstract}
Aim: Triglyceride/high-density lipoprotein cholesterol (TG/HDL-C) ratio is defined as the serum atherogenicity index. High TG/HDL-C ratio is related with vascular diseases, insulin resistance and metabolic syndrome. The TG/HDL-C ratio in cerebrovascular diseases, especially in silent cerebral lesions hasn't been well studied. The aim of this study was to evaluate the frequency of silent cerebral ischemia (SCI) and leukoaraiosis (LA), and its relationship with TG/HDL-C ratio in patients admitted with the first ischemic stroke attack. Material and Methods: We retrospectively evaluated 200 patients who admitted to Bulent Ecevit University Faculty of Medicine, Department of Neurology with the diagnosis of acute first ischemic stroke. Silent cerebral lesions were defined as LA and SCI with magnetic resonance imaging. TG/HDL-C ratio was calculated by dividing TG levels by HDL-C levels. Results: Silent cerebral lesions were detected 124 (83.2\%) of 149 patients. LA severity was evaluated according to Fazekas score, 22 (14.8\%) of patients were grade 0, $49(32.9 \%)$ of them were grade 1 , and $78(52.3 \%)$ of them were advanced periventricular white matter hyperintensity (adv-PWMH) group. TG/HDL-C ratio in SCI group was higher than the group without SCI, but it wasn't statistically significant $(p=0.091)$. A significant increase was observed in the TG/HDL-C ratio, as LA severity increased. TG/HDL-C ratio was significantly higher in adv-PWMH group ( $\mathrm{p}=0.050)$.

Conclusion: High serum atherogenicity index is associated with atherosclerosis and vascular endothelial dysfunction. With this simple, inexpensive and effective test method, high-risk group of LA and SCI could be identified.

Keywords: Silent cerebral ischemia; leukoaraiosis; TG/HDL-C ratio; serum atherogenic index.
\end{abstract}

ÖZ

Amaç: Trigliserid/yüksek yoğunluklu lipoprotein kolesterol (TG/HDL-K) oranı serum aterojenite indeksi olarak tanımlanmıştır. Yüksek TG/HDL-K oranı vasküler hastalıklar, insülin direnci ve metabolik sendrom ile ilişkilidir. Serebrovasküler olaylarda özellikle sessiz serebral lezyonlarda TG/HDL-K oranı ile ilgili çalışmalar azdır. Bu çalışmanın amacı, ilk iskemik inme atağı ile başvuran hastalarda sessiz serebral iskemi (SSİ) ve lökoariozis (LA) sıklığını ve TG/HDL-K oranı ile ilişkisini değerlendirmektir.

Gereç ve Yöntemler: Bülent Ecevit Üniversitesi Tıp Fakültesi Nöroloji bölümüne akut ilk iskemik inme tanısı ile başvuran 200 hasta geriye dönük olarak değerlendirildi. Manyetik rezonans görüntüleme ile sessiz serebral lezyonlar SSİ ve LA olarak tanımlandı. TG/HDL-K oranı TG değerinin HDL-K değerine bölünmesi ile hesaplandı.

Bulgular: Yüz kırk dokuz hastanın $124(\% 83,2)$ 'ünde sessiz serebral lezyon saptandı. LA şiddeti Fazekas skorlamasına göre değerlendirildi, hastaların $22(\% 14,8)$ 'si grade 0,49 (\%32,9)'u grade 1 ve $78(\% 52,3)$ 'i ileri düzey periventriküler beyaz cevher lezyonu (advanced periventricular white matter hyperintensity, adv-PWMH) grubundayd. SSI grubunda TG/HDL-K oranı SSI olmayan gruba göre daha yüksek bulundu, ancak istatistiksel olarak anlamlı değildi $(\mathrm{p}=0,091)$. LA şiddeti arttıkça TG/HDL-K oranında anlamlı bir artış olduğu izlendi. TG/HDL-K oranı, adv-PWMH grubunda anlamlı derecede yüksek idi $(\mathrm{p}=0,050)$.

Sonuç: Yüksek serum aterojenite indeksi ateroskleroz ve vasküler endotelyal disfonksiyon ile ilişkilidir. Bu basit, ucuz ve etkili test yöntemi ile LA ve SSİ yüksek risk grubu belirlenebilir. Anahtar kelimeler: Sessiz serebral iskemi; lökoariozis; TG/HDL-K oranı; serum aterojenite indeksi.

$\overline{\text { Presented as a poster at 55th National Neurology Congress, (November 15-21, 2019, Antalya, Turkey) }}$ 


\section{INTRODUCTION}

Stroke is a common, serious, and disabling health-care problem. Stroke is the second leading cause of death and a major cause of disability worldwide. World Health Organization has defined stroke as a clinical signs of focal or global disturbance of cerebral function, with symptoms lasting 24 hours or longer, or leading to death, with no apparent cause other than of vascular origin (1).

Stroke is associated with high mortality, morbidity, hospitalization rate and serious economic burden in developing countries. Knowing and preventing risk factors for stroke is important for a new direction to treatment approaches and take early measures $(1,2)$.

Silent cerebral lesions have been defined as leukoaraiosis (LA) and silent cerebral ischemia (SCI). SCI has been defined as ischemic lesions in patients without neurological symptoms and a history of stroke $(3,4)$. LA is cerebral white matter abnormalities which is characterized by demyelination and ischemic injury $(5,6)$.

Studies have shown that SCI and LA increase the risk of stroke, mortality and morbidity after stroke $(3,4,7)$. Thus, detecting and preventing risk factors of SCI and LA have gained prominence. It has been shown that various risk factors and pathophysiological mechanisms for SCI and LA. Lipohyalinosis, atherosclerosis and endothelial dysfunction are among these $(8,9)$. The well-known risk factor is serum cholesterol level. According to international guidelines, it is recommended to control lipid profile, especially low density lipoprotein (LDL) levels (10). Recent studies have shown that LDL particle types are more important than their total amount for vascular complications $(9,11)$. It has been determined that small dense low density lipoprotein (LDL) and small high density lipoprotein (HDL) particles are more effective for the development of atherosclerosis. According to studies, there is a strong relationship between high triglyceride/high density lipoprotein cholesterol (TG/HDL-C) ratio and plasma small dense LDL ratio (12). Atherogenic index of plasma (AIP) is calculated as the ratio between the TG value and $\mathrm{HDL}-\mathrm{C}$ value $(\mathrm{mg} / \mathrm{dL})$. (TG/HDL-C) AIP is a major risk factor for metabolic syndrome, cardiovascular diseases and insulin resistance (9,13-15). Total cholesterol/triglyceride (TC/TG) ratio is another index which reflects LDL particle size (9). There are few studies about the role of TG/HDL-C ratio in silent cerebral lesions in cerebrovascular diseases (16).

In this study, we aimed to evaluate the relationship between TG/HDL-C ratio and silent cerebral lesions in patients with first ischemic stroke.

\section{MATERIAL AND THE METHODS Participants}

Two hundred patients, who admitted to Zonguldak Bulent Ecevit University Faculty of Medicine, Department of Neurology, with first-ever ischemic stroke between 2016 and 2019 were recorded retrospectively. Patients with cerebral or subarachnoid hemorrhage, symptomatic stroke history and under 35 years of age were excluded. Demographic data of the patients (age, gender, body mass index, diabetes mellitus, hypertension, ischemic heart disease, hyperlipidemia, smoking, alcohol and drug use) was recorded retrospectively. Fifty-one patients with diabetes mellitus, hypertension, ischemic heart disease, hyperlipidemia, atrial fibrillation, smoking, alcohol use, use of antiplatelet, anticoagulant, antihypertensive or antilipidemic medication and subjects with missing covariate data were excluded the study. Lipid profiles included total cholesterol (TC), LDL cholesterol, HDL-C and TG were recorded in 149 patients. The TG/HDL-C ratio was calculated after dividing absolute TG levels by absolute HDL-C levels in peripheral blood. TG/HDL-C ratio (AIP) and TC/TG ratios were calculated. Our study was approved by Bulent Ecevit University Clinical Research Ethics Committee (29.04.2020, 09/6).

\section{Magnetic Resonance Imaging Protocol}

Magnetic resonance imaging (MRI) findings of the patients were recorded. 1.5 Tesla MRI (PHILIPS, INTERA) was used to identify silent cerebral lesions. It is scanned in 22 sections and 5 millimeters thickness. T1 (TR/TE: 582/15), T2 (TR/TE: 5835/110), T2 FLAIR (TR/TE: 6000/120), Diffusion (TR/TEd: 4832/81) and ADC (TR/TEd: 4832/81) sections were analyzed.

SCI was defined as focal hyperintensity on FLAIR and T2weighted images, hypointensity on T1-weighted image, lesions of 3-20 mmin size. Under $3 \mathrm{~mm}$ lesions seen hyperintensity on T2-weighted image, hypointesity on T1weighted and FLAIR, were described as Virchow-Robin Space $(3,4)$.

LA severity was evaluated by Fazekas scale $(17,18)$ :

Grade 0: No white matter lesions.

Grade 1: Small-sized white matter lesion adjacent to the ventricle (punctate)

Grade 2: White matter lesion that holds $1 / 3$ of ventricular cerebral cortex distance

Grade 3: White matter lesion that holds $2 / 3$ of ventricular cerebral cortex distance

Grade 2-3 lesions were considered as advanced periventricular white matter hyperintensity (adv-PWMH). MRI results of the patients were examined by two different neurologists and a common decision was reached.

\section{Statistical Analysis}

Statistical analysis was performed using the SPSS v.18.0 program. The suitability of the normal distribution was assessed by Kolmogorov-Smirnov test. When the parametric test assumptions were provided Independent Samples t test was used to compare two groups in terms of numerical variables, and the Mann-Whitney $U$ test was used when parametric test assumptions were not provided. One-way analysis of variance (ANOVA) was used to compare three groups when the parametric test assumptions were provided, and the Kruskal-Wallis test was used when not provided. Categorical variables were analyzed by Pearson Chi-square test. Descriptive statistics were given as mean \pm standard deviation or median with interquartile range and minimum maximum depending on the distribution of the continuous variables, while categorical variables were summarized as numbers and percentages. A p value of 0.05 was considered significant.

\section{RESULTS}

One hundred forty nine patients included in our study. Seventy nine $(53.0 \%)$ patients were female, seventy $(47.0 \%)$ patients were male, and the mean age was $66.5 \pm 12.6$ years. SCI was detected in $83.2 \%(n=124)$ of the patients. $12.9 \%$ of the lesions were single and $87.1 \%$ of the 
lesions were multiple. According to the Fazekas scoring, $22(14.8 \%)$ of the patients were in the grade $0,49(32.9 \%)$ of the patients were in the grade 1 , and $78(52.3 \%)$ of the patients in adv-PWMH group. The prevalence of LA and SCI was high in patients with the first ischemic stroke attack. The demographic features of the groups with and without SCI were summarized in Table 1. When the groups with SCI $(n=124)$ and without SCI $(n=25)$ were compared, no statistically significant difference was observed with TC, TG, LDL-C, HDL-C. Although TG/HDL-C ratio was high in patients with SCI, it wasn't statistically significant $(\mathrm{p}=0.091)$. TC/TG ratio was low in patients with SCI but it wasn't statistically significant $(\mathrm{p}=0.084$, Table 2$)$.

The comparison of the patients' demographic features according to Fazekas scores were summarized in Table 3. There was an increase in LA severity with age $(\mathrm{p}<0,001)$, but no relation was found between gender and LA severity $(\mathrm{p}=0.458)$.

No statistically significant difference was observed in LA severity with HDL-C, LDL-C, TC, TG values. However, LA severity was significantly associated with high TG/HDL-C ratio $(p=0.050)$. TG/HDL-C ratio was significantly higher in the adv-PWMH group (Table 4). In the adv-PWMH group, TC/TG ratio was lower, but it was not statistically significant $(\mathrm{p}=0.089)$.

\section{DISCUSSION}

Leukoaraiosis is associated with dementia, cognitive impairment, stroke risk, and small vessel diseases that increase infarct progression (19). Studies have shown that; a history of stroke, hypertension, diabetes mellitus, age, cerebral vessel atherosclerosis are known as risk factors for LA $(7,19,20)$. The cause of LA is not known exactly, but the precise mechanisms and prognostic significance in LA are still actively investigated.

Although many studies have shown that hyperlipidemia is associated with the severity of $\operatorname{LA}(7,19,21)$, this relationship has not been shown in others (22). The relationship between TG and LA severity is conflicting in recent studies. While some studies have shown that low TG level was associated with LA $(19,21)$, some studies have shown that high TG level was associated with LA (23). The mechanisms of the relationship between LA and TG level are not clearly known.

Table 1. Comparison of demographic characteristics of the patients with and without SCI

\begin{tabular}{lccc}
\hline & $\begin{array}{c}\text { With SCI } \\
(\mathbf{n = 1 2 4})\end{array}$ & $\begin{array}{c}\text { Without SCI } \\
(\mathbf{n = 2 5})\end{array}$ & p \\
\hline Age (year), mean \pm SD & $67.4 \pm 13.8$ & $64.8 \pm 11.2$ & 0.282 \\
Gender, n (\%) & & & \\
$\quad$ Female & $65(52.5)$ & $14(56.0)$ & 0.553 \\
$\quad$ Male & $59(47.5)$ & $11(44.0)$ & \\
\hline SCI: silent cerebral ischemia, SD: standard deviation & &
\end{tabular}

Table 3. Comparison of demographic characteristics of the patients according to Fazekas scoring

\begin{tabular}{|c|c|c|c|c|}
\hline & $\begin{array}{c}\text { Grade } 0 \\
(n=22)\end{array}$ & $\begin{array}{c}\text { Grade } 1 \\
(n=49)\end{array}$ & $\begin{array}{c}\text { adv-PWMH } \\
(n=78)\end{array}$ & $\mathbf{p}$ \\
\hline Age (year), & $56.1 \pm 11.2$ & $63.3 \pm 11.7$ & $71.5 \pm 8.9$ & 0.001 \\
\hline \multicolumn{5}{|c|}{ Gender, n (\%) } \\
\hline Female & $11(50.0)$ & $28(57.1)$ & $31(39.7)$ & \multirow{2}{*}{0.458} \\
\hline Male & $11(50.0)$ & $21(42.9)$ & $47(60.3)$ & \\
\hline
\end{tabular}

Table 2. Comparison of serum lipid values of the patients with and without SCI

\begin{tabular}{lccccccc}
\hline & \multicolumn{3}{c}{ With SCI (n=124) } & \multicolumn{3}{c}{ Without SCI (n=25) } & p \\
\cline { 2 - 6 } & Median & $\mathbf{Q}_{\mathbf{1}}-\mathbf{Q}_{\mathbf{3}}$ & Min-Max & Median & $\mathbf{Q}_{\mathbf{1}}-\mathbf{Q}_{3}$ & Min-Max & \\
\hline TC (mg/dl) & 181 & $151-204$ & $84-309$ & 174 & $149-205$ & $70-304$ & 0.755 \\
LDL-C (mg/dl) & 111.5 & $89-130$ & $28-229$ & 104 & $93-137$ & $23-232$ & 0.729 \\
HDL-C (mg/dl) & 37.9 & $30.6-42.1$ & $15.2-76.2$ & 37 & $32.7-47.5$ & $25-91$ & 0.593 \\
TG (mg/dl) & 139.5 & $96-190$ & $55-617$ & 120 & $87-163$ & $37-407$ & 0.152 \\
TG/HDL-C & 3.7 & $2.4-6.2$ & $0.8-22.9$ & 3.1 & $2.1-4.7$ & $0.9-16.3$ & 0.091 \\
TC/TG & 1.3 & $0.9-1.7$ & $0.3-3.3$ & 1.4 & $1.2-1.9$ & $0.5-3.4$ & 0.084
\end{tabular}

SCI: silent cerebral ischemia, TC: total cholesterol, LDL-C: low-density lipoprotein cholesterol, HDL-C: high-density lipoprotein cholesterol, TG: triglyceride, $\mathrm{Q}_{1}-\mathrm{Q}_{3}$ : ${ }^{\mathrm{st}}$ quartile - $3^{\text {rd }}$ quartile, Min-Max: minimum - maximum

Table 4. Comparison of serum lipid values of the patients according to Fazekas scoring

\begin{tabular}{lccccccccccc}
\hline & \multicolumn{3}{c}{ Grade 0 (n=22) } & \multicolumn{3}{c}{ Grade 1 (n=49) } & \multicolumn{3}{c}{ adv-PWMH (n=78) } & p \\
\cline { 2 - 9 } & Median & $\mathbf{Q}_{\mathbf{1}}-\mathbf{Q}_{\mathbf{3}}$ & Min-Max & Median & $\mathbf{Q}_{\mathbf{1}}-\mathbf{Q}_{\mathbf{3}}$ & Min-Max & Median & $\mathbf{Q}_{\mathbf{1}}-\mathbf{Q}_{\mathbf{3}}$ & Min-Max & \\
\hline TC (mg/dl) & 160 & $150-201$ & $89-271$ & 178 & $134-196$ & $84-249$ & 188 & $149-211$ & $70-309$ & 0.670 \\
LDL-C (mg/d) & 100 & $88-120$ & $43-168$ & 114 & $88-136$ & $23-232$ & 117 & $102-137$ & $52-186$ & 0.490 \\
HDL-C (mg/dl) & 39.8 & $28.4-39.8$ & $19.2-59$ & 36.1 & $29.3-41$ & $17-76.2$ & 34.3 & $29.2-40$ & $15.2-50.1$ & 0.280 \\
TG (mg/dl) & 119 & $87-141$ & $68-421$ & 145 & $87-203$ & $37-479$ & 143.5 & $106-186$ & $50-617$ & 0.317 \\
TG/HDL-C & 3.3 & $2.0-4.8$ & $1.3-15.1$ & 4.2 & $1.9-6.5$ & $0.8-22.9$ & 4.5 & $3.2-6.6$ & $1.2-16.3$ & 0.050 \\
TC/TG & 1.4 & $1.0-1.9$ & $0.6-2.6$ & 1.2 & $0.9-1.9$ & $0.3-3.3$ & 1.1 & $0.8-1.5$ & $0.3-2.4$ & 0.089 \\
\hline
\end{tabular}

adv-PWMH: advanced periventricular white matter hyperintensity, TC: total cholesterol, LDL-C: low-density lipoprotein cholesterol, HDL-C: high-density lipoprotein cholesterol, TG: triglyceride, $\mathrm{Q}_{1}-\mathrm{Q}_{3}: 1^{\text {st }}$ quartile $-3^{\text {rd }}$ quartile, Min-Max: minimum - maximum 
More than half of the white matter is made up of myelin, and the myelin contains about $70 \%$ lipids. The decrease in TG level and the increase in severity of LA can be explained in this way. Genetic reasons should also be kept in mind (19). Studies are needed to reveal new clues in this area.

Recent studies have shown that LDL particle types are more important than their total amount for vascular complications (11). Small-dense LDL and small HDL particles have been found to be particularly effective for the development of atherosclerosis. Small and dense LDL particles are more sensitive to oxidation. It is more atherogenic than large and cholesterol-rich LDL particles by increasing vascular permeability and reducing interest in LDL receptors. A relationship was observed between increased TG/HDL-C ratio, that is, hypertriglyceridemia and low HDL levels, and increased small and dense LDL rates (12). The TG/HDL-C ratio was shown for the first time by Gaziano et al. (24) as the AIP. It is considered to be important risk factor especially for coroner artery disease. TG/HDL-C ratio is accepted as an indicator of harmful LDL particles. A significant relationship was observed between high TG/HDL-C ratio and recurrent stroke in a study conducted by Park et al (25).

The size of the LDL particles and circulating very low density lipoprotein (VLDL) levels and TG levels are inversely proportional $(9,11)$. Therefore, it defined that LDL phenotypes based on TG/HDL-C ratios. Dense and small LDL particles, high TG/HDL-C ratio have been associated with coroner artery disease, cerebrovascular disease, metabolic syndrome and insulin resistance $(9,13$ 15). Vascular endothelial dysfunction is associated with an increase in TG/HDL-C ratio and vascular endothelial dysfunction has been demonstrated in LA formation (22). The changes in brain microvascular endothelial activity causing cerebral small vessel disease, which is primarily responsible for the pathogenesis of LA. Dysfunction of vascular endothelial cells causes increased permeability of the blood brain barrier (26). Blood brain barrier disorder, disruption of cerebrovascular autoregulation, and chronic hypoperfusion are important mechanisms for the development of LA. Vascular endothelial dysfunction is a potential risk factor for the development of white matter lesions (27). In this study, we observed that the relationship between high TG/HDL-C ratio with severity of LA, especially in the advanced LA group. This strengthens the relationship between LA and vascular endothelial dysfunction. This is the first study to show the relationship between serum atherogenicity index and LA. SCI is a common subclinical pathophysiology before ischemic stroke $(3,4,7,9)$. Many risk factors and pathophysiological mechanisms have been identified for SCI development. Lipohyalinosis, atherosclerosis and endothelial dysfunction are among these $(8,9)$. It has been shown in many studies that hyperlipidemia is a risk factor for SCI $(3,4,7)$. Patients with multiple SCI had higher LDL and TC levels than the patients with single SCI (7). In the study investigating the relationship between the high TG/HDL-C ratio and the presence of SCI in healthy individuals with silent cerebral ischemia, a significant relationship was found between the high TG/HDL-C ratio and the presence of SCI. It was concluded that the high TG/HDL-C ratio is responsible for atherogenicity, small and dense LDL is more sensitive to oxidation and accelerates atherosclerosis (9). Atherosclerosis also causes extravasation of toxic substances into neuronal tissues, blockage of small arterioles and hypoperfusion (28).

The relationship between high TG/HDL-C ratio and SCI prevalence can be thought to be related to atherosclerosis. In our study, when the groups with and without SCI were compared, the TG/HDL-C ratio was high in the groups with SCI, but it was not statistically significant. TC/TG ratio was found to be low in the patients with SCI but it was not statistically significant.

\section{CONCLUSION}

Leukoaraiosis and SCI increase the risk of stroke and affect mortality and morbidity after stroke. Therefore, determination and prevention of risk factors of SCI and LA has gained prominence. High serum atherogenicity index is associated with atherosclerosis and vascular endothelial dysfunction. With this simple, inexpensive and effective test method could identify high-risk group of LA and SCI. Development of LA and SCI can be prevented by this method. There is a need for new prospective studies on this subject.

Ethics Committee Approval: The study was approved by the Ethics Committee of Bulent Ecevit University Faculty of Medicine (29.04.2020, 09/6).

Conflict of Interest: None declared by the authors.

Financial Disclosure: None declared by the authors.

Acknowledgements: None declared by the authors.

\section{REFERENCES}

1. Donkor ES. Stroke in the 21st century: A snapshot of the burden, epidemiology, and quality of life. Stroke Res Treat. 2018;2018:3238165.

2. Bradley WG, Daroff RB, Fenichel GM, Jankovic J. Neurology in Clinical Practice. Çeviri: Tan E, Erdem Özdamar S. Ankara: Veri Medikal Yayıncılık; 2008. p.1165-1170.

3. Vermeer SE, Longstreth WT Jr, Koudstaal PJ. Silent brain infarcts: systematic review. Lancet Neurol. 2007;6(7):611-9.

4. Oh SH, Kim NK, Kim SH, Kim JK, Kim HS, Kim WC, et al. The prevalence and risk factor analysis of silent brain infarction in patients with first-ever ischemic stroke. J Neurol Sci. 2010;293(1-2):97-101.

5. Ay H, Arsava EM, Rosand J, Furie KL, Singhal AB, Schaefer PW, et al. Severity of leukoaraiosis and susceptibility to infarct growth in acute stroke. Stroke 2008;39(5):1409-13.

6. Ovbiagele B, Saver JL. Cerebral white matter hyperintensities on MRI: current concepts and therapeutic implications. Cerebrovasc Dis. 2006;22(23):83-90.

7. Acıman Demirel E, Emre U, Ünal A, Özen B, Atasoy HT, Öztürk F. Evaluation of silent cerebral lesions in patients with first ischemic stroke attack. Neurol Psychiat Br. 2012;18(1); 22-6.

8. Inoue K, Matsumoto M, Shono T, Toyokawa S, Moriki A. Increased intima media thickness and 
atherosclerotic plaques in the carotid artery as risk factors for silent brain infarcts. J Stroke Cerebrovasc Dis. 2007; 16(1):14-20.

9. Nam KW, Kwon HM, Jeong HY, Park JH, Kwon H, Jeong SM. High triglyceride/HDL cholesterol ratio is associated with silent brain infarcts in a healthy population. BMC Neurol. 2019;19(1):147.

10. Powers WJ, Rabinstein AA, Ackerson T, Adeoye OM, Bambakidis NC, Becker K, et al. 2018 guidelines for the early management of patients with acute ischemic stroke: a guideline for healthcare professionals from the American Heart Association/American Stroke Association. Stroke. 2018;49(3):e46-110.

11. da Luz PL, Favarato D, Faria-Neto JR Jr, Lemos P, Chagas AC. High ratio of triglycerides to HDLcholesterol predicts extensive coronary disease. Clinics (Sao Paulo). 2008;63(4):427-32.

12. Söğüt E, Avcı E, Üstüner F, Arıkan E. The evaluation of (TG/HDL-C) ratio as a serum atherogenic index. Türk Klinik Biyokimya Derg. 2006;4(1):1-8.

13. Pacifico L, Bonci E, Andreoli G, Romaggioli S, Di Miscio R, Lombardo CV, et al. Association of serum triglyceride-to-HDL cholesterol ratio with carotid artery intima-media thickness, insulin resistance and nonalcoholic fatty liver disease in children and adolescents. Nutr Metab Cardiovasc Dis. 2014;24(7):737-43.

14. Hermans MP, Ahn SA, Rousseau MF. The atherogenic dyslipidemia ratio $[\log (\mathrm{TG}) / \mathrm{HDL}-\mathrm{C}]$ is associated with residual vascular risk, beta-cell function loss and microangiopathy in type 2 diabetes females. Lipids Health Dis. 2012;11:132.

15. Deng QW, Wang H, Sun CZ, Xing FL, Zhang HQ, Zuo L, et al. Triglyceride to high-density lipoprotein cholesterol ratio predicts worse outcomes after acute ischaemic stroke. Eur J Neurol. 2017;24(2):283-91.

16. Kılıç Çoban E. Can TG/HDL ratio be an accurate predictor in the determination of the risk of cerebrovascular events in youngsters? Sisli Etfal Hastan Tip Bul. 2018;52(3):201-5.

17. Scheltens P, Erkinjunti T, Leys D, Wahlund LO, Inzitari D, del Ser T, et al. White matter changes on CT and MRI: an overview of visual rating scales. European
Task Force on Age-Related White Matter Changes. Eur Neurol. 1998;39(2):80-9.

18. Fazekas F, Chawluk JB, Alavi A, Hurtig HI, Zimmerman RA. MR signal abnormalities at $1.5 \mathrm{~T}$ in Alzheimer's dementia and normal aging. AJNR Am J Neuroradiol. 1987;8(3):421-6.

19. Ke D, Zhou F, Liang H, Xu Y, Lou H. Hypertriglyceridemia is associated with reduced leukoaraiosis severity in patients with a small vessel stroke. Behav Neurol. 2018;2018:1361780.

20. Vedala K, Nagabandi AK, Looney S, Bruno A. Factors associated with leukoaraiosis severity in acute stroke patients. J Stroke Cerebrovasc Dis. 2019;28(7):1897901.

21. Jimenez-Conde J, Biffi A, Rahman R, Kanakis A, Butler C, Sonni S, et al. Hyperlipidemia and reduced white matter hyperintensity volume in patients with ischemic stroke. Stroke. 2010;41(3):437-42.

22. Lin J, Wang D, Lan L, Fan Y. Multiple factors involved in the pathogenesis of white matter lesions. BioMed Res Int. 2017;2017:9372050.

23. Park K, Yasuda N, Toyonaga S, Yamada SM, Nakabayashi H, Nakasato M, et al. Significant association between leukoaraiosis and metabolic syndrome in healthy subjects. Neurology. 2007;69(10):974-8.

24. Gaziano JM, Hennekens CH, O'Donnell CJ, Breslow JL, Buring JE. Fasting triglycerides, high-density lipoprotein, and risk of myocardial infarction. Circulation 1997;96(8):2520-5.

25. Park JH, Lee J, Ovbiagele B. Nontraditional serum lipid variables and recurrent stroke risk. Stroke. 2014;45(11):3269-74.

26. Guan J, Yan C, Gao Q, Li J, Wang L, Hong M, et al. Analysis of risk factors in patients with leukoaraiosis. Medicine. 2017;96(8):e6153.

27. Hoth KF, Tate DF, Poppas A, Forman DE, Gunstad J, Moser DJ, et al. Endothelial function and white matter hyperintensities in older adults with cardiovascular disease. Stroke. 2007;38(2):308-12.

28. Nam KW, Kwon HM, Jeong HY, Park JH, Kim SH, Jeong SM, et al. Cerebral white matter hyperintensity is associated with intracranial atherosclerosis in a healthy population. Atherosclerosis 2017;265:179-83. 